\title{
Organo-sulfur Carcinogen
}

National Cancer Institute

\section{Source}

National Cancer Institute. Organo-sulfur Carcinogen. NCI Thesaurus. Code C45190.

An organic compound that has sulfur incorporated into its structure and exposure to this compound can increase the risk of human cancer. ( $\mathrm{NCl05)}$ 